\title{
PERTANGGUNGJAWABAN HUKUM BIDAN AKIBAT PELIMPAHAN WEWENANG OLEH DOKTER DALAM PELAYANAN KESEHATAN DI PUSKESMAS
}

Siti Nur Asyah Jamillah Ahmad, Sutarno, Yulianto

Fakultas Hukum Universitas Hang Tuah

J1 Arief Rahman Hakim 150 Surabaya Telp. 0315945894031594 5894, e-mail:

Sitinurahmad17@yahoo.com

\begin{abstract}
Abstrak
Penelitian ini memberikan gambaran mengenai Pertanggungjawaban Hukum Bidan Akibat Pelimpahan Wewenang Oleh Dokter Dalam Pelayanan Kesehatan Di Puskesmas". Bidan memberikan pelayanan kesehatan harus sesuai dengan standar profesi, standar pelayanan, standar prosedur operasional dan ketentuan yang berlaku. Bidan bertugas memberikan pelayanan kesehatan ibu dan anak, pelayanan kebidanan, dan melaksanakan pelimpahan kewenangan tindakan medis. Pelayanan kesehatan oleh bidan atas pelimpahan wewenang oleh dokter juga dapat menimbulkan malpraktik, sehingga pasien dapat menuntut secara pidana maupun perdata. Oleh karena itu, perlu adanya pertanggungjawaban hukum bidan maupun dokter jika tidak sesuai dengan standar, dengan melihat unsur kesalahan, kelalaian, dan wanprestasi yang berpedoman pada rekam medis
\end{abstract}

Kata kunci: tanggung jawab, bidan, pelayanan kesehatan

\section{A.Pendahuluan}

Pasal 28H Undang-Undang Dasar Negara Republik Indonesia Tahun 1945 menyatakan bahwa : "Setiap orang berhak hidup sejahtera lahir dan batin, bertempat tinggal, dan mendapatkan lingkungan hidup yang baik dan sehat serta berhak memperoleh pelayanan kesehatan".

Pasal 1 ayat (6) Undang Undang Nomor 36 Tahun 2009 tentang Kesehatan, menyatakan yang dimaksud dengan tenaga kesehatan adalah : "Setiap orang yang mengabdikan diri dalam bidang kesehatan serta memiliki pengetahuan dan/atau keterampilan melalui pendidikan di bidang kesehatan untuk jenis tertentu memerlukan kewenangan untuk melakukan upaya kesehatan".

Bidan merupakan salah satu tenaga profesi dalam bidang kesehatan. Bidan dalam melakukan praktik kebidanan harus sesuai dengan standar. Undang-Undang Nomor 36 Tahun 2014 tentang Tenaga Kesehatan dalam pasal 58 ayat (1) huruf a menyebutkan bahwa : "Tenaga Kesehatan dalam menjalankan praktik wajib memberikan pelayanan kesehatan sesuai dengan Standar Profesi, Standar Pelayanan Profesi, Standar Prosedur 
Operasional, dan etika profesi serta kebutuhan kesehatan Penerima Pelayanan Kesehatan”. Adapun yang dimaksud dengan standar adalah pedoman yang harus dipergunakan sebagai petunjuk dalam menjalankan profesi. Selanjutnya pada pasal 65 Undang-Undang Nomor 36 Tahun 2014 tentang Tenaga Kesehatan juga menyebutkan tentang pelimpahan kewenangan bagi tenaga kesehatan.

Peraturan Menteri Kesehatan Republik Indonesia Nomor 28 Tahun 2017 tentang Izin dan Penyelenggaraan Praktik Bidan pasal 1 ayat (1) menyatakan bahwa : "Bidan adalah seorang perempuan yang lulus dari pendidikan bidan yang telah teregistrasi sesuai dengan ketentuan peraturan perundangundangan".

Pelayanan kebidanan merupakan layanan yang diberikan oleh bidan sesuai dengan kewenangan yang dimilikinya dengan tujuan meningkatkan kesehatan ibu dan anak guna tercapainya keluarga yang berkualitas, bahagia, dan sejahtera. Sasaran pelayanan kebidanan adalah individu, keluarga, dan masyarakat, yang meliputi upaya peningkatan, pencegahan, penyembuhan serta pemulihan. ${ }^{1}$

Penyelenggaraan praktik bidan diatur dalam Peraturan Menteri

\footnotetext{
${ }^{1}$ Suryani Soepardan, (2007), Suryani Soepardan, Konsep Kebidanan, Jakarta: Buku Kedokteran EGC, hlm. 29.
}

Kesehatan Republik Indonesia Nomor 28 Tahun 2017. Peraturan Menteri Kesehatan Republik Indonesia Nomor 28 Tahun 2017 pasal 22 menyatakan tentang pelimpahan kewenangan berupa mandat yang diberikan oleh dokter, dan pada pasal 27 ayat (4) menyatakan bahwa : "Tindakan pelayanan kesehatan sebagaimana dimaksud pada ayat (1) menjadi tanggung jawab dokter pemberi mandat, sepanjang pelaksanaan tindakan sesuai dengan pelimpahan yang diberikan".

Bidan dapat memberikan pelayanan kesehatan sesuai dengan mandat dokter di bawah pengawasan dokter. Selain itu, dalam melakukan tindakan medis tertentu dokter juga tidak dapat melaksanakan sendiri, tetapi dibantu oleh bidan yang berada di tempat pelayanan kesehatan dalam hal ini di Puskesmas.

Permasalahannya adalah apabila dokter memberikan pelimpahan wewenang kepada bidan untuk melakukan suatu tindakan, tindakan yang dilimpahkan oleh dokter yang dilakukan bidan menimbulkan malpraktik, apakah tanggung jawab sepenuhnya ada pada dokter selaku pemberi pelimpahan wewenang atukah tanggung jawab bidan sebagai penerima pelimpahan yang telah melakukan malpraktik. Aturan tersebut juga tidak memuat penjelasan mengenai 
bentuk tindakan pelayanan kesehatan seperti apa yang dapat dilimpahkan pada bidan secara mandat. Kesalahan dalam pemberian mandat juga dapat berpotensi besar menimbulkan bahaya.

Bidan dalam menjalankan praktiknya harus sesuai dengan standar, baik standar pelayanan, standar profesi, dan standar operasional prosedur. Peraturan Menteri Kesehatan Republik Indonesia Nomor 28 Tahun 2017 tentang Izin dan Penyelenggaraan Praktik Bidan pasal 29 menyebutkan bahwa :"Dalam melaksanakan praktik kebidanannya, bidan memiliki hak memperoleh perlindungan hukum sepanjang melaksanakan pelayanannya sesuai dengan standar profesi, standar pelayanan, dan standar prosedur operasional".

Peraturan Menteri Kesehatan Republik Indonesia Nomor 28 Tahun 2017 tentang Izin dan Penyelenggaraan Praktik bidan pasal 46 ayat (4) menyatakan bahwa : "Dalam rangka pelaksanaan pengawasaan sebagaimana dimaksud pada ayat (1), Menteri, Dinas Kesehatan Provinsi, Dinas Kesehatan kabupaten/Kota, dapat memberikan tindakan administratif kepada bidan yang melakukan pelanggaran terhadap ketentuan penyelenggaraan praktik bidan".
Perlu diketahui bahwa, bahwa permasalahannya bukan berkenaan dengan pelaksanaan kegiatan-kegiatan yang bersifat medis dalam pelayanan kesehatan, melainkan berkenaan dengan pertanggungjawaban masing-masing pelaksana jabatan menurut peraturan perundang-undangan. Permasalahan akan terjadi apabila bidan yang melakukan tindakan pelayanan kesehatan tidak kompoten sehingga dapat menimbulkan kerugian pada pengguna jasa pelayanan kesehatan, mulai dari kerugian ringan hingga pada kematian.

Disinilah akan timbul permasalahan hukum akibat pelimpahan wewenang, dengan bentuk pertanggungjawaban hukumnya baik secara pidana maupun perdata, terhadap siapakah beban tanggung jawab pidana dan perdata selayaknya dibebankan.

Berdasarkan uraian latar belakang masalah tersebut diatas, maka masalah yang akan dikaji sekaligus menjadi legal issue adalah tanggung jawab hukum bagi bidan akibat malpraktik atas dasar pelimpahan wewenang oleh dokter dalam pelayanan kesehatan di puskesmas.

\section{B. Metode Penelitian}

Penelitian ini merupakan penelitian yuridis normatif, yaitu penelitian yang mencari pemecahan atas isu hukum yang 
timbul untuk memberikan preskripsi mengenai apa yang seyogyanya atas isu. ${ }^{2}$ Pendekatan permasalahan yang digunakan dalam penelitian ini adalah pendekatan perundang-undangan (statute approach) dan pendekatan konseptual (conseptual Approach). ${ }^{3}$

Penggunaan pendekatan ini dimaksudkan agar memperoleh kajian yang menyeluruh mengenai hal-hal yang berkaitan dengan pertanggungjawaban hukum bidan akibat pelimpahan wewenang oleh dokter.

Pendekatan perundang-undangan (statute approach) dilakukan dengan menelaah sudut filosofis peraturan perundang-undangan yang mengatur mengenai pertanggungjawaban akibat pelimpahan wewenang, baik secara pidana maupun perdata, sedangkan pendekatan konseptual (conseptual Approach) dilakukan dengan beranjak dari pandangan-pandangan dan konsepkonsep yang berkembang mengenai hal tersebut.

Selanjutnya untuk dapat menjawab permasalahan dalam penelitian ini diperlukan sumber-sember penelitian yang dapat dipergunakan sebagai bahan

2 Peter Mahmud Marzuki, (2005), Penelitian Hukum, Jakarta: Kencana Premadia Group, hlm. 59.

${ }^{3}$ Johnny Ibrahim, (2008), Teori \& Metodologi Penelitian Hukum Normatif, Malang: Bayumedia, hlm. 310-320. hukum, yang terdiri atas bahan hukum primer berupa peraturan perundangundangan, bahan hukum sekunder berupa semua tulisan ilmiah tentang hukum dan kesehatan yang telah dipublikasikan meliputi buku-buku, jurnal dan makalah, serta bahan hukum tersier berupa Kamus Hukum, Kamus Bahasa Indonesia, dan Kamus Kebidanan.

\section{Pembahasan}

Pelimpahan kewenangan

Kewenangan yang sah bila ditinjau dari sumber darimana kewenangan itu lahir atau diperoleh, maka terdapat tiga kategori kewenangan, yaitu atributif, delegatif dan mandat, yang dapat dijelaskan sebagai berikut : ${ }^{4}$

a. Kewenangan atributif

Kewenangan atributif biasanya digariskan atau berasal dari adanya pembagian kekuasaan oleh peraturan perundang-undangan. Dalam pelaksanaan kewenangan atributif ini pelaksanaannya dilakukan sendiri oleh pejabat atau badan yang tertera dalam peraturan dasarnya terhadap kewenangan atributif mengenai tanggung jawab dan tanggung gugat berada pada pejabat atau badan sebagaimana tertera dalam peraturan dasarnya.

\footnotetext{
${ }^{4}$ Nur Basuki Winanmo. (2008). Penyalahgunaan Wewenang dan Tindak Pidana Korupsi, Laksbang Mediatama, Yogyakarta, hlm. 70-75.
} 
b. Kewenangan delegatif

Kewenangan delegatif bersumber dari pelimpahan suatu organ pemerintah kepada organ lain dengan dasar peraturan perundang-undangan. Dalam hal ini kewenangan delegatif tanggung jawab dan tanggung gugat beralih kepada yang diberi wewenang tersebut dan beralih pada delegataris.

c. Kewenangan mandat

Kewenangan mandat merupakan kewenangan yang bersumber dari proses atau prosedur pelimpahan dari pejabat atau badan yang lebih tinggi kepada pejabat atau badan yang lebih rendah. Kewenangan mandat terdapat hubungan rutin atasan dan bawahan, kecuali bila dilarang secara tegas.

Delegasi harus memenuhi syaratsyarat sebagai berikut:

a. Delegasi harus definitif, artinya delegasi tidak dapat lagi menggunakan sendiri wewenang yang telah dilimpahkan itu;

b. Delegasi harus berdasarkan ketentuan perundang-undangan, artinya delegasi hanya dimungkinkan jika ada ketentuan yang memungkinkan untuk itu dalam peraturan perundangundangan;

c. Delegasi tidak kepada bawahan, artinya dalam hierarki kepagawaian tidak diperkenankan adanya delegasi; d. Kewajiban memberi keterangan (penjelasan), artinya delegans berwenang untuk meminta penjelasan tentang pelaksanaan wewenang tersebut;

e. Peraturan kebijakan (beleidsregel), artinya delegans memberikan instruksi (petunjuk) tentang penggunaan wewenang tersebut. ${ }^{5}$

Pelimpahan kewenangan kepada tenaga kesehatan diatur dalam UndangUndang Kesehatan Nomor 36 Tahun 2014 tentang Tenaga Kesehatan pasal 65 ayat yang menyatakan bahwa :

(1) Dalam melakukan pelayanan kesehatan, Tenaga Kesehatan dapat menerima pelimpahan tindakan medis dari tenaga medis.

(2) Dalam melakukan pekerjaan kefarmasi -an, tenaga teknis kefarmasian dapat menerima pelimpahan pekerjaan kefarmasian dari tenaga apoteker.

(3) Pelimpahan tindakan sebagaimana dimaksud pada ayat (1) dan ayat (2) dilakukan dengan ketentuan:

a. tindakan yang dilimpahkan termasuk dalam kemampuan dan keterampilan yang telah dimiliki oleh penerima pelimpahan;

b. pelaksanaan tindakan yang dilimpahkan tetap di bawah pengawasan pemberi pelimpahan;

${ }^{5}$ Ibid, hlm.94.

Volume 2 No.1 April 2018

ISSN Cetak: 2579-9983, E-ISSN: 2579-6380

Halaman.164-184 
c. pemberi pelimpahan tetap bertanggung jawab atas tindakan yang dilimpahkan sepanjang pelaksanaan tindakan sesuai dengan pelimpahan yang diberikan; dan

d. tindakan yang dilimpahkan tidak termasuk pengambilan keputusan sebagai dasar pelaksanaan tindakan;

e. Ketentuan lebih lanjut mengenai pelimpahan tindakan sebagaimana dimaksud pada ayat (1), ayat (2), dan ayat (3) diatur dengan Peraturan Menteri.

Penjelasan pasal yang yang dimaksud dengan tenaga kesehatan dalam ketentuan ini, antara lain adalah perawat, bidan, penata anestesi, tenaga keterapian fisik, dan keteknisian medis. Selanjutnya pelimpahan kewenangan oleh dokter kepada bidan diatur dalam Peraturan Menteri Kesehatan Nomor 28 Tahun 2017 tentang Izin dan Penyelenggaraan Praktik Bidan pasal 22 huruf b yang menyatakan bahwa: "Pelimpahan wewenang melakukan tindakan pelayanan kesehatan secara mandat dari dokter". Kemudian pasal 27 yang menyatakan bahwa :

(1) Pelimpahan wewenang melakukan tindakan pelayanan kesehatan secara mandat dari dokter sebagaimana dimaksud dalam Pasal 22 huruf $b$ diberikan secara tertulis oleh dokter pada Fasilitas Pelayanan Kesehatan tingkat pertama tempat Bidan bekerja.

(2) Tindakan pelayanan kesehatan sebagaimana dimaksud pada ayat (1) hanya dapat diberikan dalam keadaan di mana terdapat kebutuhan pelayanan yang melebihi ketersediaan dokter di Fasilitas Pelayanan Kesehatan tingkat pertama tersebut.

(3) Pelimpahan tindakan pelayanan kesehatan sebagaimana dimaksud pada ayat (1) dilakukan dengan ketentuan:

a. tindakan yang dilimpahkan termasuk dalam kompetensi yang telah dimiliki oleh Bidan penerima pelimpahan;

b. pelaksanaan tindakan yang dilimpahkan tetap di bawah pengawasan dokter pemberi pelimpahan;

c. tindakan yang dilimpahkan tidak termasuk mengambil keputusan klinis sebagai dasar pelaksanaan tindakan; dan

d. tindakan yang dilimpahkan tidak bersifat terus menerus.

(4) Tindakan pelayanan kesehatan sebagaimana dimaksud pada ayat (1) menjadi tanggung jawab dokter pemberi mandat, sepanjang 
pelaksanaan tindakan sesuai dengan pelimpahan yang diberikan.

Pelimpahan wewenang secara delegatif yang diberikan oleh dokter kepada bidan, secara jelas belum diatur, berbeda dengan profesi keperawatan yang telah diatur dalam undang-undang keperawatan.

Walaupun, dalam peraturannya menyebutkan tentang pelimpahan wewenang secara mandat oleh dokter kepada bidan, namun secara jelas belum mengatur tentang jenis tindakan apa yang dilimpahkan, misalkann tindakan penyuntikan dan pemasangan infus merupakan tindakan yang dapat dilimpahkan secara delagatif ataukah secara mandat.

Tanggung Jawab Pidana

Hukum kesehatan merupakan hukum "lex specialis", melindungi secara khusus tugas profesi kesehatan (provider) dalam program pelayanan kesehatan manusia menuju ke arah tujuan deklarasi "helath for all" untuk mendapatkan pelayanan kesehatan. ${ }^{6}$ Setiap tindakan medis selalu mengandung resiko, sekecil apapun tindakan medis, dapat saja

${ }^{6}$ Cecep Triwibowo, (2014), Etika dan Hukum Kesehatan, Yogyakarta: Nuha Medika, hlm. 16. menimbulkan resiko yang besar, sehingga dapat saja pasien menderita kerugian.

Dasar pertanggungjawaban pidana adalah kesalahan. Salah dalam arti hukum pidana terdiri dari kesalahan dapat berbentuk sengaja (opzet) atau lalai $(\text { culpa })^{7}$, untuk lebih jelasnya adalah sebagai berikut :

a. Sengaja (opzet)

Menurut doktrin inti dari sengaja (opzet) itu ialah kehendak seseorang. Kehendak (will) itu dapat ditujukan kepada perbuatan itu sendiri, dan dinamakan "formeel opzet", dan dapat pula ditujukan pada "akibat perbuatan" atau masalah atau keadaan, dan disebut pula sebagai "materieel opzet". Selanjutnya dijelaskan bahwa pembagian opzet (kesengajaan) itu menurut doktrin yaitu sebagai berikut :

1) Sengaja sebagai maksud (Opzet Als Ooghmerk)

2) Sengaja dengan keinysafan (Opzet Bij Zekerheidsbewustzijn).

3) Sengaja dengan keinsyafan kemungkinan (Opzet Bijmogelijkeheids bewustzijn)

b. Kealpaan, sebagaimana yang disebut dalam pasal 359 KUH Pidana

Simons menerangkan "kealpaan" bahwa pada umumnya kealpaan itu terdiri

7 Rasyid Ariman dan Fahmi Raghib, (2016), Hukum Pidana, Malang: Setara Press, hlm.222. 
atas dua bagian, yaitu tidak berhati-hati melakukan suatu perbuatan, disamping dapat menduga akibat perbuatan itu. Pada umumnya kealpaan (culpa) dibedakan atas :

1) Kealpaan dengan kesadaran (Bewuste schuld).

2) Kealpaan tanpa kesadaran (Onbewestu schuld).

Dalam kepustakaan, disebutkan bahwa untuk adanya kesalahan, terdakwa harus dipenuhi dengan empat unsur, yaitu : melakukan perbuatan pidana (sifat melawan hukum), diatas umur tertentu dapat bertanggung jawab, mempunyai bentuk kesalahan yang berupa kesengajaan atau kealpaan, tidak adanya alasan pemaaf.

Ajaran sifat melawan hukum memiliki kedudukan yang penting dalam hukum pidana di samping asas legalitas. Ajaran ini terdiri dari ajaran sifat melawan hukum yang formal dan materil

a. Ajaran sifat melawan hukum formal

Sifat melawan hukum formal terjadi karena memenuhi rumusan delik undangundang. Sifat melawan hukum formal merupakan syarat untuk dapat dipidananya perbuatan.

b. Ajaran sifat melawan hukum materil

Ajaran ini mengakui alasan-alasan pembenar di luar undang-undang, dengan kata lain, alasan pembenar dapat pembenar dapat berada pada hukum yang tidak tertulis. ${ }^{8}$

Unsur-unsur yang tidak dapat menghapus pertanggungjawaban pidana menurut Pompe :

a. Suatu kemampuan berpikir pada pembuat yang harus memungkinkan dia menguasai pikirannya dan menentukan kehendaknya atau kemauannya;

b. Dapat mengerti makna dan akibat perbuatannnya;

c. Dapat menentukan kehendaknya sesuai dengan jalan pikirannya. Kemampuan berpikir sebagaimana tersebut di atas terdapat pada orang normal. ${ }^{9}$

Dalam bidang hukum, hukum pidana termasuk dalam hukum yang berlaku umum, dimana setiap orang harus tunduk kepada peraturan ini dan pelaksanaan peraturan ini dapat dipaksakan.

Setiap anggota masyarakat (dokter dan bidan) tanpa kecuali harus taat, juga termasuk orang asing yang berada dalam yuridiksi Negara Republik Indonesia. Tuntutan malpraktik berdasarkan hukum pidana (dengan kata lain sebagai

8 Salim HS, (2006), Perkembangan Hukum Kontrak Innominaat di Indonesia, Jakarta: Sinar Grafika, hlm. 21.

9 Tina Asmarawati, (2014), Pidana dan Pemidanaan dalam Sistem Hukum di Indonesia, Yogyakarta: Deepublish, hlm. 61.

Volume 2 No.1 April 2018

ISSN Cetak: 2579-9983, E-ISSN: 2579-6380

Halaman.164-184 
kriminalitas dalam bidang medik) yang tercatat dalam literatur-literatur sebenarnya tidaklah banyak. Meskipun demikian, perlu diketahui beberapa perbuatan yang dikategorikan dalam malpraktik pidana, antara lain: ${ }^{10}$

a. Penganiyaan (Mishandeling)

Malpraktik kedokteran dapat menjadi penganiyaan jika ada kesengajaan, baik terhadap perbuatan maupun akibat perbuatan. Perbuatan pada penganiyaan harus berwujud, misalnya pemukulan atau pembedahan tubuh yang dilakukan oleh dokter/bidan. Akan tetapi bisa juga dengan perbuatan pasif, seperti sengaja tidak segera melakukan pembedahan tindakan yang menurut ilmu kesehatan/kedokteran harus dilakukan segera dengan maksud agar pasien mati.

Dalam perlakuan tersebut berarti terjadi penganiyaan yang menyebabkan matinya orang. Penganiyaan hanya berlaku kesengajaan sebagai maksud (opzet als oogmerk) saja, tidak termasuk kesengajaan sebagai kemungkinan.

b. Kealpaan yang menyebabkan kematian

Pasal 359 merumuskan bahwa "barang siapa karena kesalahannya kealpaannya menyebabkan orang lain mati...." jadi disamping adanya sikap batin culpa harus ada tiga unsur lagi. Tiga

${ }^{10}$ Chorisdiono M. Achadiat, (2006), Dinamika Etika dan Hukum Kedokteran (dalam Tantangan Zaman), Jakarta: Buku Kedokteran EGC, hlm. 29. unsur yang dimaksud merupakan rincian dari kalimat : "menyebabkan orang lain mati" yakni : $:^{11}$

a. Harus ada wujud perbuatan;

b. Adanya akibat berupa kematian;

c. Adanya causal verband antara wujud perbuatan dengan akibat kematian.

c. Kealpaan yang menyebabkan luka-luka Dugaan malpraktik dalam bidang pelayanan kesehatan selain karena kematian juga bisa disebabkan karena adanya luka, yang tertuang dalam tindak hukum pidana. Menurut pasal 360 ayat (1).

Adami Chazawi menilai tidak semua malpraktik medis masuk dalam ranah hukum pidana. Ada tiga unsur yang harus dipenuhi, yaitu : sikap batin dokter (ada kesengajaan/dolus atau culpa), tindakan medis yang dilakukan melanggar standar profesi kedokteran, standar prosedur operasional, atau mengandung sifat melawan hukum, tidak sesuai dengan kebutuhan pasien, dan menimbulkan lukaluka (pasal 360 KUH Pidana) atau kehilangan nyawa pasien (pasal $359 \mathrm{KUH}$ Pidana).

Malpraktik yang dilakukan dengan sikap batin culpa hanya diterapkan pada pasal 359 KUH Pidana (jika menyebabkan kematian pasien), pasal 360

11 Adami Chazawi, (2005), Pelajaran Hukum Pidana Bagian I, Jakarta: PT. Raja Grafindo, hlm. 106.

Volume 2 No.1 April 2018

ISSN Cetak: 2579-9983, E-ISSN: 2579-6380

Halaman.164-184 
KUH Pidana (jika menyebabkan luka berat) dan tindak pidana aborsi (aborsi criminalis) pada pasal 347 dan pasal 348 KUH Pidana.

Pembuktian tentang ada atau tidaknya kesalahan/kelalaian yang telah dilakukan oleh bidan merupakan syarat utama untuk mepertanggungjawabkan pelayanan kesehatan yang dilakukannya. Doktrin Res Ispa Loquitor (the thing spekas for it self) dengan mudah dapat membuktikan tentang adanya kesalahan yang dilakukan oleh bidan.

Penegakkan tindak pidana malpraktik dalam pelayanan kesehatan masih menggunakan ketentuan-ketentuan yang diatur dalam Undang-Undang Nomor 29 Tahun 2004 tentang Praktik Kedokteran, Undang-Undang Nomor 44 Tahun 2009 tentang Rumah Sakit, serta Undang-Undang Nomor 36 Tahun 2009 tentang Kesehatan tidak mengatur secara khsusus atau tidak dikenal adanya tindak pidana akibat malpraktik. Tetapi, dimuat dalam pasal 84 Undang-Undang Nomor 36 Tahun 2014 tentang Tenaga Kesehatan mengenai ketentuan pidana, yang menyatakan bahwa :

(1)Setiap Tenaga Kesehatan yang melakukan kelalaian berat yang mengakibatkan Penerima Pelayanan Kesehatan luka berat dipidana dengan pidana penjara paling lama 3 (tiga) tahun;

(2)Jika kelalaian berat sebagaimana dimaksud pada ayat (1) mengakibatkan kematian, setiap Tenaga Kesehatan dipidana dengan pidana penjara paling lama 5 (lima) tahun.

Dari defenisi malpraktik adalah "kelalaian dari seorang dokter untuk mempergunakan tingkat kepandaian dan ilmu dalam mengobati dan merawat pasien, yang lazim dipergunakan terhadap pasien atau orang yang terluka menurut ukuran di lingkungan yang sama". (Valentin v. La Society de Bienfaiscance Mutualle de Los Angelos, California, 1956). Dari defenisi tersebut malpraktik harus dapat dibuktikan apakah benar telah terjadi kelalaian oleh tenaga kesehatan atau tenaga medis dalam menerapkan ilmu dan ketrampilannya yang ukurannya lazim dipergunakan di wilayah tersebut, tenaga kesehatan disini juga meliputi bidan. Sehingga tidak serta merta tenaga kesehatan ataupun tenaga medis dituntut yang disebabkan oleh malpraktik.

Karena perikatan dalam transaksi terapeutik yang terjadi antara tenaga kesehatan ataupun tenaga medis dengan pasien adalah perikatan/perjanjian jenis daya upaya (ispaning verbintenis) dan bukan perjanjian akan hasil (resultat verbintenis). 
Penentuan secara normatif tentang ada atau tidaknya kelalaian atas tindakan yang dilakukan oleh dokter dan bidan harus ditinjau secara cermat dan teliti kasus per kasus. Hakim yang memegang kunci dalam menentukan secara in concreto tentang ada atau tidaknya melakukan pekerjaan sesuai dengan standar profesi dan tidak sesuai prosedur tindakan, dikatakan telah melakukan kesalahan/kelalaian.

Oleh karena itu, pelimpahan wewenang yang diberikan dokter kepada bidan baik secara delegatif ataupun mandat, jika terjadi malpraktik tidak sepenuhnya hanya ditanggung oleh dokter sendiri ataupun bidan sendiri, pertanggungjawaban pidana baik bagi dokter ataupun bidan apabila terjadi malpraktik yang menimbulkan kerugian pada pasien perlu dilakukan telaah kasusnya terlebih dahulu, dalam hal ini perlu membuka rekam medis, jika dalam pelaksanaannya tindakan yang dilakukan oleh bidan tidak sesuai dengan standar prosedur ketika menerima pelimpahan wewenang secara mandat dari dokter maka bidan juga turut serta untuk bertanggungjawab hukum, namun dalam hal ini juga dokter tidak dapat melepaskan tanggung jawabnya ketika memberikan pelimpahan wewenang secara delegatif, kesalahan dalam memberikan pelimpahan tindakan oleh dokter kepada bidan juga dapat berakibat fatal pada pasien. Pertanggungjawaban hukum pidana bagi bidan, dengan tetap memperperhatikan unsur-unsur pidana yang dilakukan bidan, yaitu sebagai berikut:

a. Suatu perbuatan yang bersifat melawan hukum, dalam hal ini apabila bidan melakukan pelayanan kesehatan di luar kewenanangannya yang tertuang dalam Peraturan Menteri Kesehatan Nomor 28 Tahun 2017 tentang Izin dan Penyelenggaraan Praktik Kebidanan.

b. Mampu bertanggung jawab, dalam hal ini bidan memahami konsekuensi dari setiap tindakannya dan secara kemampuan telah mendapat pelatihan dan pendidikan untuk itu.

c. Adanya kesalahan (schuld) berupa kesengajaan atau karena kealpaan (culpa). Apabila tindakan tersebut dilakukan karena adanya niat dan unsur kesengajaan maka bidan dijerat sebagai pelaku tindak pidana. Sebagai contoh seorang bidan dengan sengaja memberikan suntikan dengan sengaja agar pasien meninggal.

d. Tidak adanya alasan pembenar dan atau alasan pemaaf, dalam hal ini tidak ada alasan pemaaf seperti tidak adanya aturan yang mengijinkannya melakukan suatu tindakan, ataupun tidak ada alsan pembenar dan pemaaf 
seperti resiko yang melekat dalam tindakan yang dilakukan. Secara umum pertanggungjawaban pidana seorang bidan adalah mandiri, tidak seperti perdata maupun adminstrasi.

Pertanggungjawaban pidana bagi bidan akibat pelimpahan wewenang yang diberikan oleh dokter jika merujuk pada pasal 55 KUH Pidana yang menyatakan bahwa :

(1) Dipidana sebagai si pembuat tindak pidana

Ke-1. orang yang melakukan, yang menyuruh melakukan dan turut serta melakukan perbuatan;

Ke-2. orang yang dengan memberi atau menjanjikan sesuatu, dengan menyalahgunakan kekuasaan atau martabat, dengan kekerasan, ancaman atau penyesatan, atau dengan memberi kesempatan, sarana atau keterangan, sengaja menganjurkan orang lain.

Dalam pasal 55 ayat (1), mengandung makna bahwa :

a. Pertama kelompok orang-orang yang perbuatannya disebutkan dalam pasal 55 ayat (1) yang dalam hal ini adalah para pembuat

1) Yang melakukan (plegen) orangnya disebut dengan pembuat pelaksana (pleger);

2) Yang menyuruh melakukan (doenplegen), orangnya disebut dengan pembuat penyuruh (doenpleger);

3) Yang turut serta melakukan (medeplegen), orangnya disebut dengan pembuat peserta (medepleger);

4) Yang sengaja menganjurkan (uitlokken), yang orangnya disebut dengan pembuat penganjur (uitlokker).

b. Kedua yakni orang yang disebut dengan pembuat pembantu (medeplechtige) kejahatan, yang dibedakan menjadi :

1) Pemberian bantuan pada saat pelaksanaan kejahatan;

2) Pemberian bantuan sebelum pelaksanaan kejahatan. $^{12}$

Pasal 56 KUH Pidana merumuskan bahwa: Sebagai pembantu melakukan kejahatan dipidana :

Ke-1. Orang yang dengan sengaja membantu waktu kejahatan itu dilakukan;

Ke.2. Orang yang dengan sengaja memberi kesempatan, ikhtiar atau keterangan untuk melakukan kejahatan itu.

Pasal 57 KUH Pidana merumuskan

${ }^{12}$ Hendra F. Sidabutar, (2008), Penerapan Pasal 55 KUHP (Deelneming) terhadap Penanganan Tindak Pidana Pemalsuan Ijazah (Studi Putusan No. 2876/P ID B/2006 PN Medan) Studi Putusan No. 2877/ $P$ ID B/2006/PN, Medan: Salemba Empat, hlm. 28. 
(1) Maksimum pidana pokok yang diancamkan atas kejahatan dikurangi sepertiganya, bagi pembantu;

(2) Jika kejahatan itu dapat dipidana dengan pidana mati atau dengan pidana penjara seumur hidup, maka dijatuhkanlah pidana penjara yang selama-lamanya lima belas tahun;

(3) Pidana tambahan untuk kejahatan dan membantu melakukan kejahatan itu, adalah sama.

(4) Pada menentukan pidana hanya diperhatikan perbuatan yang sengaja dimudahkan atau dibantu oleh pembantu itu, serta dengan akibat perbuatan itu.

Moeljatno dalam bukunya menulis bahwa pasal 55 sampai 62 KUHP Pidana, sebagai pasal-pasal yang mengenai penyertaan. Dikatakan ada penyertaan apabila bukan satu orang saja yang tersangkut dalam terjadinya perbuatan pidana, akan tetapi beberapa orang. Yang dapat dinamakan peserta harus memenuhi syarat-syarat yaitu sebagai orang yang melakukan atau turut serta melakukan perbuatan pidana atau membantu melakukan perbuatan pidana. ${ }^{13}$ Berangkat dari pasal 55, 56 dan 57 KUH Pidana bagi bidan maupun dokter dapat dituntut secara pidana.

13 Moeljatno, (1985), Delik-Delik Percobaan Delik-Delik Penyertaan, Jakarta: Bina Aksara, hlm. 63-64.
Pelimpahan kewenangan secara mandat oleh dokter kepada bidan jika merujuk pada pasal 55 KUH Pidana yaitu sebagai orang yang menyuruh melakukan, dimana dalam tindak pidana ini, pelakunya paling sedikit dua orang, yakni orang yang menyuruh dan disuruh.

Orang yang menyuruh dapat dihukum sebagai orang yang melakukan tindak pidana sedang orang yang disuruh tidak dapat dihukum karena tidak dapat bertanggungjawab dengan memenuhi beberapa syarat yaitu karena gila, terpaksa, perintah jabatan yang tidak syah, dan tidak dapat disalahkan samasekali. Merujuk pada pasal 56 KUH Pidana, pelimpahan kewenangan secara mandat, sebagai kategori pembantu, bidan dapat dituntut apabila melakukan tindakan kejahatan secara sengaja, sedangkan pasal 57 KUH Pidana bagi pembantu dapat dikurangi sepertiga.

Ketiga pasal ini dapat diberlakukan pada tindak pidana sebagai akibat pelimpahan wewenang secara mandat. Namun perlu diktehaui semua tindakan yang dilakukan perlu ditelaah terlebih dahulu, kasus perkasus dimanakah letak kesalahannya.. Dokter atau bidan tidak dapat dituntut jika telah melakukan tindakan sesuai dengan standar yang berlaku. 
Pelimpahan wewenang secara delegatif dengan pengalihan tanggung jawab hukum kepada bidan, bukan berarti dokter melepas tanggung jawab apabila terjadi malpraktik yang menyebabkan kehilangan nyawa dan luka berat pada pasien. Oleh karena itu, perlu dikaji lagi karena kesalahan perintah dokter juga dapat menimbulkan akibat yang fatal bagi pasien.

Perlu adanya pembuktian bahwa prosedur yang sudah dilaksanakan sudah sesuai atau belum yang sesuai dengan standar profesi dan ilmu kedokteran/kebidanan, yang dilakukan oleh bidan maupun dokter, untuk membuktikan yang bertanggungjawab.

Tanggung Jawab Perdata

Dalam ilmu hukum dikenal tiga (3) kategori dari perbuatan melawan hukum, yaitu sebagai berikut $:{ }^{14}$ Perbuatan melawan hukum karena kesengajaan, perbuatan melawan hukum tanpa kesalahan (tanpa unsur kesengajaan maupun kelalaian), perbuatan melawan hukum karena kelalaian.

Maka model tanggung jawab hukum adalah sebagai berikut $:^{15}$ Tanggung jawab dengan unsur kesalahan (kesengajaan dan kelalaian) sebagaimana

14 Munir Fuady, (2002), Perbuatan Melawan Hukum, Bandung: Citra Aditya Bakti, hlm. 3.

${ }^{15}$ Ibid. terdapat dalam pasal 1365 KUH Perdata, tanggung jawab dengan unsur kesalahan khususnya kelalaian sebagaimana terdapat dalam pasal 1366 KUH Perdata, tanggung jawab mutlak (tanpa kesalahan) sebagaimana terdapat dalam pasal 1367 KUH Perdata.

Ada beberapa unsur kesalahan perdata menurut Abdulkadir Muhamamad, yaitu : ${ }^{16}$ Pelanggaran hak, unsur kesalahan, dan kerugian yang diderita

Adapaun dasar hukum gugatan berdasarkan perbuatan melawan hukum di dalam hukum kesehatan terdapat dalam beberapa ketentuan, yaitu :

a. Pasal 58 Undang-Undang Nomor 36 Tahun 2009 tentang Kesehatan yang menyatakan bahwa : "Setiap orang berhak menuntut ganti rugi terhadap seseorang, tenaga kesehatan, dan /atau penyelenggara kesehatan yang menimbulkan kerugian akibat kesalahan atau kelalaian dalam pelayanan kesehatan yang diterimanya”. Berdasarkan ketentuan ini pasien dapat menggugat bidan ataupun dokter yang serta puskesmas yang menimbulkan kerugian pada pasien.

b. Pasal 32 q Undang-Undang Nomor 44 Tahun 2009 tentang Rumah Sakit :

\footnotetext{
${ }^{16}$ Abdulkadir Muhammad, (1989), Hukum

Perjanjian, Alumni, Bandung: Alumni, hlm. 197.
} 
"Setiap pasien mempunyai hak menggugat dan/atau menuntut Rumah Sakit apabila rumah sakit diduga memberikan pelayanan yang tidak sesuai standar baik secara perdata maupun secara pidana”. Pasal ini membuka kemungkinan untuk menggugat tenaga kesehatan dan tenaga medis secara pidana maupun perdata. Namun ketentuan seperti yang disebutkan tersebut belum diatur dalam pelayanan kesehatan yang dilaksanakan di puskesmas.

c. Pasal 77 Undang-Undang Nomor 36 Tahun 2014 tentang Tenaga Kesehatan menyatakan bahwa: "Setiap Pelayanan Kesehatan yang dirugikan akibat kesalahan atau kelalaian Tenaga Kesehatan dapat meminta ganti rugi sesuai dengan ketentuan Peraturan Perundang-undangan”. Berdasarkan rumusan pasal ini tenaga kesehatan dalam hal ini bidan dapat dimintai pertanggungjawaban oleh pasien apabila menimbulkan kerugian pada pasien.

d. Pasal 1365 KUH Perdata yang menyatakan bahwa : "Tiap perbuatan melawan hukum yang membawa kerugian pada orang lain mewajibkan orang yang karena salahnya menimbulkan kerugian itu mengganti kerugian tersebut". Tenaga kesehatan ataupun tenaga medis dapat dimintai pertanggungjawaban hukum berdasarkan pasal tersebut.

e. Pasal 1366 KUH Peradata, yang menyatakan bahwa : "Setiap orang bertanggungjawab tidak saja untuk kerugian yang disebabkan karena perbuatannya tetapi juga untuk kerugian yang disebabkan karena kelalainya". Tenaga kesehatan ataupun tenaga medis jika karena kelalaiannya menimbulkan kerugian pada pasien dapat dimintakan pertanggungjawaban berdasarkan rumusan pasal tersebut.

f. Pasal 1367 KUH Perdata yang menyatakan bahwa : "Seorang tidak saja bertanggung jawab untuk kerugian yang disebabkan karena perbuatannya sendiri, tetapi juga untuk kerugian yang disebabkan karena perbuatan orang-orang yang menjadi tanggungannya atau disebabkan oleh barang-barang yang berada di bawah pengawasannya”. Pertanggungjawaban berdasarkan pasal ini dikaitkan dengan pertanggungjawaban berdasarkan pelimpahan wewenang yaitu secara mandat, maka dokter juga bertanggung jawab secara perdata selaku pemberi pelimpahan wewenang, dengan tetap melakukan pembuktian terlebih dahulu terhadap rekam medis yang ada, untuk mengetahui dimanakah letak kesalahan 
yang ada sesuai dengan standar prosedur operasional, ataukah kesalahan pelimpahan wewenang yang diberikan oleh dokter.

g. Pasal 1371 KUH Perdata : "Penyebab luka atau cacatnya sesuatu anggota badan dengan sengaja atau karena kurang hati-hati memberikan hak kepada si korban untuk selain penggantian biaya-biaya penyembuhan, menuntut penggantian kerugian yang disebabkan oleh luka atau cacat tersebut. Juga penggantian kerugian ini dinilai menurut kedudukan dan kemampuan kedua belah pihak dan menurut keadaan. Ketentuan paling akhir ini pada umumnya berlaku dalam hal menilaikan kerugian, yang diterbitkan dari suatu kejahatan terhadap pribadi seseorang si korban untung.

h. Undang-Undang Nomor 29 Tahun 2004 tentang Praktik Kedokteran, utamanya pasal 45 ayat (1), (2), dan (3) persetujuan dokter dan pasien dikenal dengan informed consent.

Membandingkan bunyi Pasal 46 Undang-Undang Nomor 44 Tahun 2009 tentang Rumah Sakit dengan Pasal 1367 KUHPerdata ayat (3) di atas, dapat diambil kesimpulan bahwa Pasal 46 Undang-Undang Nomor 44 tahun 2009 tentang Rumah Sakit adalah derivate atau turunan dari Pasal 1367 KUH Perdata ayat (3) yang berlaku khusus untuk kalangan Rumah Sakit, atau Pasal 46 Undang-Undang Nomor 44 Tahun 2009 bersifat lex spesialis. Ketentuan Pasal diatas juga sejalan dengan ketentuan dari doktrin respondeat superior. Doktrin respondeat superior mengandung makna bahwa seorang majikan adalah orang yang berhak untuk memberikan instruksi dan mengontrol tindakan bawahannya, baik atas hasil yang dicapai maupun tentang cara yang digunakan. Di samping itu dengan perkembangan hukum kesehatan dan kecanggihan teknologi kedokteran, rumah sakit pun tidak dapat melepaskan diri dari tanggung jawab pekerjaan yang dilakukan oleh pegawainya, termasuk apa yang diperbuat oleh para medis. ${ }^{17}$

Jika dikaitkan pada doktrin respondeat superior maka, dapat dianalogikan hubungan dokter dan bidan akibat pelimpahan wewenang secara mandat. Namun doktrin ini tidak dapat diterapkan begitu saja, karena untuk penerapannya harus terlebih dulu dipenuhi syarat-syarat tertentu, seperti harus adanya hubungan kerja antara atasan dengan bawahan dan sikap tindak bawahan harus pula dalam ruang lingkup pekerjaan yang ditugaskan kepadanya.

17 Bahder Johan Nasution, (2005), Hukum Kesehatan Pertanggungjawaban Dokter, Jakarta,: Rineka Cipta, hlm. 72.

Volume 2 No.1 April 2018

ISSN Cetak: 2579-9983, E-ISSN: 2579-6380

Halaman.164-184 
Hubungan kerja dianggap ada, apabila atasan mempunyai hak secara langsung mengawasi dan mengendalikan aktivitas bawahan dalam melakukan tugastugasnya, dalam hal ini pekerjaan yang dilakukan harus merupakan suatu wujud perintah yang diberikan oleh atasan. ${ }^{18}$

Pelimpahan wewenang yang diberikan oleh dokter kepada bidan secara delegatif, dimana terjadi pengalihan tanggung jawab bagi yang menerima pelimpahan wewenang yaitu bidan, jika terjadi malpraktik dan mengakibatkan kerugian bagi pasien, tidak hanya bidan sendiri yang bertanggungjawab secara hukum, dokter juga ikut bertanggungjawab hukum, sebab dapat terjadi oleh karena kesalahan memberikan pelimpahan wewenang. Oleh karena itu, perlu dilakukan telaah terhadap rekam medis dimanakah letak kesalahan yang terjadi, apakah telah sesuai dengan standar operasional prosedur atau tidak.

Tanggung gugat hukum yang ditujukan kepada bidan dan dokter sebagai pemberi pelimpahan wewenang secara delegasi kepada bidan yang melakukan kelalaian yang mengakibatkan timbulnya kerugian bagi pasien dalam pelayanan kesehatan di puskesmas tetap dikenai tanggung jawab hukum, namun tetap harus melakukan telaah terhadap

${ }^{18}$ Ibid. rekam medis yang ada, apakah tindakan yang diberikan telah sesuai dengan standar prosedur atau tidak. Tuntutan atau gugatan perdata yang dapat diajukan (tanggung gugat hukum) seperti telah disebutkan sebelumnya adalah:

a. Tanggung gugat berdasarkan wanprestasi atau cedera janji atau ingkar janji yang didasarkan pada contractual liability sebagaimana diatur dalam Pasal 1239 KUH Perdata.

b. Tanggung gugat berdasarkan perbuatan melanggar hukum (onrechtmatigedaad) sebagaimana diatur dalam ketentuan Pasal 1365 dan 1366 KUH Perdata.

Terdapat dua bentuk ganti rugi akibat perbuatan melawan hukum, yaitu :

a. Ganti rugi materiil

Kerugian materiil adalah kerugian yang nyata-nyata diderita oleh korban dan jumlahnya dapat diukur secara matematis. b. Ganti rugi immateriil

Kerugian imateriil merupakan kerugian pihak korban yang tidak dapat diukur jumlahnya. Ganti rugi immateriil dapat berupa penderitaan sakit atau kesakitan, kesedihan, ketakutan, kehilangan kesenangan, kehilangan harapan, kehilangan bagian tubuh atau cacat, bahkan sampai kematian pasien bukan kerugian yang dapat dituntut atas dasar wanprestasi. Ganti rugi immateriil 
ini hanya dapat dibebankan terhadap kerugian karena perbuatan melawan hukum dan tidak layak diterapkan atas kerugian yang disebabkan oleh wanprestasi kontrak.

Perikatan tanggung renteng diatur dalam pasal 1278 KUH Perdata sampai dengan Pasal 1295 KUH Perdata. Perikatan tanggung renteng menurut pasal 1278 KUH Perdata adalah: ${ }^{19}$ Perikatan tanggung renteng adalah : "suatu perikatan dimana beberapa orang bersama-sama sebagai pihak yang berutang berhadapan dengan satu orang kreditor, dimana salah satu dari debitur itu telah membayar utangnya pada kreditor, maka pembayaran itu akan membebaskan teman-teman yang lain dari utang". ${ }^{20}$ Tanggung renteng didefinisikan sebagai tanggung jawab bersama diantara anggota dalam satu kelompok atas segala kewajiban terhadap koperasi dengan dasar keterbukaan dan saling mempercayai. ${ }^{21}$

Bentuk ganti rugi yang ditimbulkan karena kesalahan atau kelalaian sebagai akibat pelimpahan wewenang dokter kepada bidan secara mandat dimana

\footnotetext{
${ }^{19}$ R. Subekti dan R. Tjitrosudibio, (2001), Kitab Undang-Undang Hukum Perdata, Jakarta: Pradnya Paramita, hlm. 330.

20 Salim, (2009), Pengantar Hukum Perdata Tertulis, Jakarta: Sinar Grafika, hlm. 176.

21 Gatot Supriyanto, (2009), Aplikasi Sistem Tanggung Renteng Koperasi Setia Bhakti Wanita Jawa Timur, Surabaya: Kopwan Setia Bhakti Wanita, hlm. 36.
}

tanggung jawabnya melekat pada dokter maka, tetap dikaji berdasarkan pembuktian berdasarkan rekam medis yang ada, dan standar profesi, dan standar operasional prosedur yang ada di puskesmas, sehingga tanggung jawabnya tidak hanya melekat pada dokter tetapi juga bidan sebagai pelaksana tindakan dengan menggunakan prinsip tanggung renteng seperti kasus yang diputuskan oleh hakim dalam kasus Pitra Azmirla dan Damitri Almira.

Pertanggungjawaban perdata bagi bidan akibat pelimpahan wewenang oleh dokter berbeda jika terjadi di rumah sakit, sesuai pasal 46 Undang-Undang Rumah Sakit bahwa Rumah Sakit bertanggung jawab atas kelalaian yang ditimbulkan oleh tenaga kesehatan, namun jika kelalaian di puskesmas yang ditimbulkan oleh tenaga medis maupun tenaga kesehatan perlu dikaji lagi, karena dalam aturan tentang puskesmas tidak memuat ketentuan pertanggungjawaban hukum puskesmas atas kelalaian tenaga medis dan tenaga kesehatan

\section{Penutup}

Tanggung jawab hukum bagi bidan akibat pelimpahan kewenangan yang diberikan oleh dokter kepada bidan dalam pelayanan kesehatan di puskesmas, harus dilihat apakah perbuatan tersebut karena 
adanya unsur kesalahan dan kelalaian yang membuat orang lain menderita. Harus dilihat juga apakah tindakan tersebut dilakukan karena perbuatan melawan hukum atau karena wanprestasi. Walaupun secara teori pelimpahan kewenangan secara delegatif terjadi pengalihan tanggung jawab kepada penerima pelimpahan wewenang yaitu bidan dan mandat merupakan tanggung jawab dari pemberi pelimpahan, dalam hal ini dokter. Perlu dilakukan pembuktian dengan cara membuka rekam medis pasien yang ada di puskesmas tempat dokter dan bidan bekerja kemudian meneliti standar prosedur operasional yang ada di puskesmas.

Rekam medis memuat semua catatan tentang tindakan yang dilimpahkan oleh dokter kepada bidan dan pelaksanaan tindakan bidan. Sehingga dapat diindentifikasikan apakah bidan melakukan kesalahan atau kelalaian secara sengaja dan tidak sesuai yang dilimpahkan serta standar prosedur operasional atau oleh karena perintah dari dokter yang tidak jelas. Karena bentuk pelimpahan kewenangan tindakan yang dilimpahkan belum jelas secara peraturan perundang-undangan maka tanggung jawab juga menjadi tidak jelas.

Meskipun demikian, bidan dapat dituntut secara pidana, perdata maupun administarsi apabila secara jelas dan terbukti melalui pembuktian di pengadilan menunjukkan bahwa bidan mencederai klien sampai cacat bahkan meninggal secara sengaja atas perintah.

Berdasarkan penelitian yang telah dilakukan, saran yang dapat diberikan adalah sebagai berikut maka perlu secara jelas pembagian bentuk pelimpahan kewenangan secara jelas yaitu tindakan apa yang dilakukan di Puskesmas agar bidan memiliki batas kewenangan dalam menjalankan tugas pelimpahan. Oleh karena, profesi bidan merupakan bagian dari profesi kesehatan yang selalu berhubungan dengan keselamatan pasien, maka perlu juga dibentuk undang-undang kebidanan yang dapat memberi kejelasan mengenai penyelenggaraannya dan melindungi praktik kebidanan.

\section{E. Daftar Pustaka}

Buku

Achadiat, Chorisdiono M, (2006), Dinamika Etika dan Hukum Kedokteran (dalam Tantangan Zaman), Jakarta: Buku Kedokteran EGC.

Asmarawati, Tina, (2014), Pidana dan Pemidanaan dalam Sistem Hukum di Indonesia, Yogyakarta: Deepublish. 
Chazawi, Adami, (2005), Pelajaran

Hukum Pidana Bagian I, Jakarta:

PT. Raja Grafindo.

Fuady, Muad, (2002), Perbuatan

Melawan Hukum, Bandung: Citra Aditya Bakti.

Hamzah, Andi, (2011), Asuransi

Tanggung Jawab Produk, Jakarta:

Lembaga Studi Hukum dan

Ekonomi Fakultas Hukum

Universitas Indonesia.

Ibrahim, Johnny, (2008), Teori \& Metodologi Penelitian Hukum

Normatif, Malang: Bayumedia

Publishing.

Marzuki, Peter Mahmud, (2005),

Penelitian Hukum, Jakarta: Kencana

Premadia Group.

Moeljatno, (1985), Delik-Delik

Percobaan Delik-Delik Penyertaan,

Jakarta: Bina Aksara.

Muhammad, Abdulkadir, (2010), Hukum

Perusahaan Indonesia, Citra Aditya

Jakarta: Bakti.

Nasution, Bahder Johan, (2005), Hukum

Kesehatan Pertanggungjawaban

Dokter, Jakarta: Rineka Cipta.

Salim, (2009), Pengantar Hukum Perdata

Tertulis, Jakarta: Sinar Grafika.

Sidabutar, Hendra F, (2008) Penerapan

Pasal 55 KUHP (Deelneming) terhadap Penanganan Tindak

Pidana Pemalsuan Ijazah (Studi
Putusan No. 2876/P ID B/2006 PN

Medan) Studi Putusan No. 2877/ P

ID B/2006/PN, Medan: Salemba

Empat.

Soepardan, Suryani, (2007), Konsep

Kebidanan, Jakarta: Buku

Kedokteran EGC.

Subekti, (1989), Pokok Pokok Hukum

Perdata, Jakarta: Intermasa.

Supriyanto, Gatot, (2009), Aplikasi Sistem

Tanggung Renteng Koperasi Setia

Bhakti Wanita Jawa Timur,

Surabaya: Kopwan Setia Bhakti

Wanita.

Peraturan perundang-undangan

Undang-Undang Dasar Negara Republik Indonesia Tahun 1945.

KUH Pidana (Wetboek Van Strafrecht

Voor Nederlandsch Indie).

KUH Perdata (Burgerlijk Wetboek Voor

Indonesie).

Undang-Undang Republik Indonesia Nomor 44 Tahun 2009 tentang Rumah Sakit (Lembaran Negara Republik Indonesia Tahun 2009 Nomor 153 Tambahan Lembaran Negara Republik Indonesia Nomor 5072).

Undang-Undang Nomor 29 Tahun 2004 tentang Praktik Kedokteran (Lembaran Negara Republik Indonesia Tahun 2004 Nomor 150 
Tambahan Lembaran Negara

Republik Indonesia Tahun 4431).

Undang-Undang No.36 Tahun 2009

Tentang Kesehatan (Lembaran

Negara Republik Indonesia Tahun

2009 Nomor 144 Tambahan

Lembaran Negara Republik

Indonesia Nomor 5063).

Undang-Undang No. 36 Tahun 2014

Tentang Tenaga Kesehatan

(Lembaran Negara Republik

Indonesia Tahun 2014 Nomor 298

Tambahan Lembaran Negara

Republik Indonesia Nomor 5607).
Peraturan Menteri Kesehatan Nomor RI Nomor 75 Tahun 2014 tentang Pusat Kesehatan Masyarakat (Berita Negara Republik Indonesia Tahun 2014 Nomor).

Peraturan Menteri Kesehatan Nomor RI Nomor 28 Tahun 2017 tentang Izin dan penyelenggaraan praktik bidan (Berita Negara Republik Indonesia Tahun 2017 Nomor).

Keputusan Menteri Kesehatan Nomor 369/MENKES/SK/III/2007 tentang Standar Profesi Bidan. 